\title{
Into the Desert: Solitude in Culture and Literature
}

\author{
Svend Erik Larsen \\ Department of Aesthetics and Communication, Comparative Literature, Aarhus University, Aarhus, Denmark \\ Email: litsel@hum.au.dk
}

Received May $12^{\text {th }}, 2013$; revised June $18^{\text {th }}, 2013$; accepted July $5^{\text {th }}, 2013$

Copyright (C) 2013 Svend Erik Larsen. This is an open access article distributed under the Creative Commons Attribution License, which permits unrestricted use, distribution, and reproduction in any medium, provided the original work is properly cited.

\begin{abstract}
Most studies of solitude have focused on the modern individualized sense of solitude, located or originating in urbanized Western cultures where solitude is seen as a companion to urban modernity. In this perspective the larger historical and cultural context goes almost unnoticed together with the fact that the preoccupation with solitude, in various forms and functions, has been around for a longer time span than Modernity and with a broader cross-cultural perspective. However, the basic cultural function of the various understandings of solitude is the same across cultures: a negotiation of the boundaries of the human life world, but in forms that are historically contextualized and differentiated. With texts from William Shakespeare to J. M. Coetzee and with references to older mythology and its modern recycling this paper tries to capture the broader historical development of solitude in European culture as an imagined position on the boundary of the human life world.
\end{abstract}

Keywords: Solitude; Isolation; Desert; Monster; Boundary; Humanity; Projection; Construction

\section{The Desert and the City}

Søren Kierkegaard was once asked by the Danish king if he needed solitude to write. In his diary he noted that he responded affirmatively. When the king asked if Kierkegaard would then seek the most remote part of the country, Kierkegaard answered: No, he intended to go to Berlin-“"There I am totally alone and can work harder than ever" (Kierkegaard, 1968) Seeing the king's amazement he continued that even in the smallest hamlet "and incognito, I would not be able to find a hideout of 400,000 people." Here Kierkegaard, the ardent proponent of existentialist individualism, echoes René Descartes, the philosopher of solipsism. In Discours de la méthode (1637) he first thought that complete solitude inside his lodging would serve his contemplation best, "tout le jour enfermé seul dans un poêle" (Descartes, 1991). But soon he came to realize that the only way to develop his thought was to converse with others. So, he came to the conclusion that the best site to do so, and still remain alone, was not a recluse, but a densely populated place where, "sans manquer d'aucune des commodités qui sont dans les villes les plus fréquentées, j'ai pu vivre aussi solitaire et retiré que dans les déserts les plus écartés" (Descartes, 1991).

Here, the city would be less a space to be explored than a social paradox to be experienced: crowded modern urban life, paradoxically and inevitably, generates solitude as in a desert. Later, this observation has become common place in the social critique of urban life and of urbanized Western Modernity in general wherever it manifests itself. Just to take on example from Sunil Gangopadhyay's historical novel, Those Days (1981), from the 19th century booming Kolkata: "On his journey Nabin became aware that the solitude was a state of mind, independent of environment. Here on this bajra, though surrounded by people, he was alone, truly alone for the first time in his life." (Gangopadhyay, 1997). Everywhere solitude is a necessary companion to modern urbanity. Most studies of solitude have focused on this modern individualized sense of solitude, while the larger historical and cultural context goes almost unnoticed together with the fact that the preoccupation with solitude, in various forms and functions, has been with us for a longer time span than Modernity and with a broader crosscultural perspective than individual modern sensitivity (Engelberg, 2001; Fergusson, 1992; Hannoun, 1993; Möhrmann, 1974; Naudin, 1995).

However, the basic cultural function of the various under standings of solitude is the same across cultures: a negotiation of the boundaries of the human life world, but in forms that are historically contextualized and differentiated. In this paper I will try to capture the broader historical development of solitude in European culture as an imagined position on the boundary of the human life world.

\section{Ontological Solitude}

It is customary to think of solitude primarily in spatial terms. From this point of view, solitude is connected to an extraordinary spatial position. Some will search for it through adventurous travels to remote and unknown parts of the globe like many classical heroes or their modern counterparts: pursuing Moby Dick, confronting the heart of darkness or venturing off on space odysseys. Others are condemned to go there-by the gods, by law or by fate. The spatial reference may also reach outside the realm of human experience, as in the case of protagonists who, though still alive, embark on a katabasis into the underworld.

The solitude of the human protagonists places them beyond the ordinary space of their fellow humans, whereas the solitude of the monsters and their kin places them outside the universal categorization of things and thus outside immediate human re- 
cognition. In an encounter between humans and non-human phenomena, both are cut off from the natural architecture of the world that embraces nature and culture as a whole. Solitude means being outside this natural and recognizable order, in the human life world or in nature at large. In other words: to be one of a kind in an ontological solitude.

When protagonists leave their proper place within humankind for a solitary existence, the surrounding world also transcends the categories that keep the cosmic order in place. The interaction between these two entangled modes of solitude, the human and the non-human, takes place in strange locations to the effect that the boundaries of the human life world within the natural order of things become visible (Sheenan \& Sosna, 1991).

In King Lear (1606) (Shakespeare, 2001) shows how imaginary language may capture this situation. Here, the classical order of things and the great chain of being are out of joint. Nothing belongs clearly any longer to a cultural or natural kind. Here, at the boundary of humankind and the universal order of things, solitude is all-pervasive. Hence, all singular events also exemplify a universal catastrophe, and the non-human and the unnatural merge indistinguishably with humankind and with nature in a cataclysm of cosmic proportions.

Such an event occurs in the first act when Lear's daughter Goneril throws him out into the night. His shock and bewilderment is expressed in the imaginary language of solitude, though without first of all foregrounding his own individual feeling of solitude in that particular moment. Instead, it turns his rejection into a sign of the absence of valid structure of cultural or natural species.

Darkness and devils! [...]

Degenerate bastard! I'll not trouble thee:

Yet have I left a daughter. [...]

Ingratitude, thou marble-hearted fiend,

More hideous, when thou show'st thee in a child,

Than the sea-monster. [...]

Hear, Nature, hear! Dear Goddess, hear!

Suspend thy purpose, if thou didst intend

To make this creature fruitful

[...] If she must teem,

Create her a child of spleen, that it may live

And be thwart disnatur'd torment to her.

(I, iv, v. 249ff)

Being thrown out by one's own daughter equals a collapse of the ordered universe. In complete accordance with this situation, the general perspective on the particular event is cast as infernal cross-overs between, and beyond, the natural kinds. Now, they can only be synthesized as a curse including everything that goes against the natural order of things. It is as if "heaven's vault should crack" (V, iii, v. 258), a crack that reverberates throughout the drama from the smallest detail to the overall universal breakdown of an order that used to locate humans and things in a shared universe. This is the language of ontological solitude. Lear's solitude is interpreted as an irrevocable universal condition, culminating later in the proto-desert landscape of the heath.

Descartes and Kierkegaard have a different take on solitude. As they suggest, the role of the city shows that spatial relations continue to offer a set of useful terms with which to reflect on boundary experiences related to solitude, on the one hand, and to a shared social space on the other. However, what they also point to, indirectly but importantly, is that solitude is not an extraordinary spatial position to be sought through audacious expeditions to the boundaries of and beyond human experience. Instead, Descartes and Kierkegaard go right to and not beyond the emerging new center of ordinary modern life, the crowded city. Here, their intention is to stay within the limits of everyday life, and by way of an individual and cultural self-reflection they create an imaginary solitary space, an Archimedean point of their own making, from where to consider the limits of humanity. Like Paul Auster they invent their solitude, as it were (Auster, 1982), as part of a process which took its beginning with Petrarca in the late Middle Ages (Petrarca, 1955).

Here, solitude is not primarily identical with a particular remote spatial location wherein a particular event of potentially cosmic proportions may be staged. They take solitude to be a basic condition for individual and cultural self-reflection as an ongoing process, shaped as an imagined and constructed platform for a creative human contemplation of la condition humaine. It is available to everyone and, according to Kierkegaard, also necessary for everyone. We move from a notion of solitude as an extreme spatial position making the universe, and maybe also our own place in it, visible from its margins to a notion reflecting a cultural condition that allows us first to see ourselves and then the entire human life world around us, but hardly the entire cosmos.

\section{Emotional Solitude}

The two terms, "isolation" and "solitude", can help to clarify this apparent reduction of the spatial dimension and its horizons and describe the nature of emotional solitude. Both are words of Latin descent and came later to be part of the lexicography of modern Indo-European languages, some of which, such as English, Spanish, Portuguese or French, became global languages.

The core of "isolation" is Lat. insula, which first of all means island, that is to say a natural element of a spatial nature. But it also denotes a floor of a building, a block of houses, a neighborhood of a city that can be singled out as perceptibly detached from its surroundings, that is to say a cultural element of material and social nature belonging to the built environment. The further semantic development of the term extends its meaning to also include a human being completely dissociated from the collective structure to which he or she belongs. Whereas the first two meanings are mainly descriptive with a clear spatial denotation, the latter reduces the spatial reference and prompts instead psychological, ideological, ethical and existential significations.

The meaning of 'social isolation' addresses the relation between individuals or individual groups and their society in ethical, emotional and broader social and cultural terms. John Donne is famous for his lines: "No man is an island, entirely of itself; every man is a piece of the continent, a part of the main" (Donne, 1998). In the general meaning of isolation, the isolated element is still related to what it is isolated from-island from mainland, block from street, individual seclusion from social collectivity. In short, isolation is a term that articulates a relation. An isolated human being still belongs to humankind. Solitude is different and so is the solitary being. This term is also based on a spatial reference. It means a deserted place, the desert in particular as a specific geographical denomination. It has always been seen as a undifferentiated and infinite space, supposedly with no trace of the boundaries between the natural 
elements, the closest one could come an absolute void ( $\chi$ óo $\varsigma$ or rather $\alpha \pi \varepsilon i p o v$ or Lat. vacuum). A negative epiphany, as it were: "Dans le désert, voyez-vous, il y a tout, il y a rien ... c'est Dieu sans l'homme", Balzac's narrator aptly remarks in Une passion dans le désert (Balzac, 1977), which for Kant was a terrifying sublime experience (Kant, 1905).

Hence, every human being there would be in a state of solitude, not surrounded by anything that could be related to the known order of nature. Subsequently, "solitude" is a deserted position more than a particular place became the dominant meaning in various languages. Like ultima thule, the desert indicated the limes of Roman civilization, which is to say, civilization as such. Those who lived there were beyond civilization, barbarians or monsters, evoking all kinds of imaginings about their deficient humanity (Breitenfellner \& Kohn-Levy, 1998; Hall, 1989; Hassig, 1995; Kappler, 1980; Larsen, 2004; Sheehan \& Sosna, 1991; Wittkower, 1977). Further, beyond the deserts, strange and monstrous beings were imagined to exist, as Pliny abundantly recounts in his Historia naturalis (1st century BCE) (Pliny, 1961), which acquired a long afterlife in European imagining of the foreign, even the Old Norse saga world regarding peoples living even farther to the North. If isolation primarily points to a relational position within a larger natural or social space, solitude shows the boundary of that space and a vision of what might lie beyond.

Thus, in contrast to isolation, solitude does not refer to urban or other social spaces in particular, although the island and the desert are still active parts of our imaginary language when it comes to isolation and solitude on the edge of the world as in modern travel writing, e.g. in Geoffrey Moorhouse: "We traversed more dunes, and again I felt the deepest fear nudging me. [...] It was as though one were very close to the edge of the earth. [...] gain it, and one would drop off into eternal space." (Moorhouse, 1974). Thus, in a broader sense solitude indicates the state of being absolutely detached, not just isolated from something specific or specifiable, but from everything in terms of space, meaning, value and identity. Likewise, the cult of

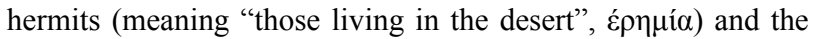
contemplative ideal of life in monasteries and convents in various religions take solitude to equal closeness to the divinities on the boundary of human existence.

This oscillation between solitude and isolation is depicted in the case of Robinson Crusoe (Defoe, 1965; Engelberg, 2001). $\mathrm{He}$ is "all alone on an uninhabited island". Robinson is more than alone, he is all alone. He is not just isolated, that is to say placed on an island, he is on an uninhabited island. As people in this borderland or beyond it does not count as humans, so Friday does not at the beginning of their encounter qualify as a human inhabitant. However, to Robinson's amazement, he is both docile and malleable, a cannibal more receptive to humanization than Shakespeare's swearing and cunning Caliban, although only fit for a subservient human position - a noble savage, in line with ideas originating in the Renaissance. Hence, Robinson's solitude is more than just spatial and social. At the outset, he is just one of a kind.

This position not only belongs to a boundary space like an uninhabited island, but also any being living there challenges the boundary between known natural or cultural species: Robinson is both a man from urbanized and imperial England and is at the same time bound to a primitive pre-civilized life; being a cannibal Friday is close to the savage animal world but is at the same time an amicable human being. The status of being one of a kind points imaginatively to the stable order of things, while at the same time transcending this order. The basic endeavor is to overcome solitude through an allegedly humanizing process that makes Friday a fellow human being with whom Robinson now shares, not solitude but isolation within the recognizable borders of humankind, a shared fate which can then be overcome in the novel's final social vision.

The same humanizing response to solitude can be seen when we approach the boundary of humankind from the outside. Frankenstein's monster sees the uninhabited and uninhabitable "desert mountains and dreary glaciers" (Shelley, 2000) as his proper place when he, in emotional turmoil, realizes he solitude on human conditions:

Believe me, Frankenstein: I was benevolent; my soul glowed with love and humanity: but am I not alone, miserably alone? You, my creator, abhor me; what hope can I gather from your fellow-creatures, who owe me nothing? They spurn and hate me. The desert mountains and dreary glaciers are my refuge. (Shelley, 2000)

$\mathrm{He}$ is one of a kind, both in relation to humankind and to the natural order at large. This is so in spite of his capacity to feel and to talk and thus to contemplate his fate and his split identity as non-human in a proto-human disguise. He abhors his own body that inspires horror in others when he makes a serious attempt to approach the idyllic cottage of the De Lacey family.

But earlier on, by observing closely the life of the cottagers from his solitary outpost in the nearby forest, he teaches himself to talk and to read just as Friday learned from Robinson. However, his linguistic fluency does not compensate for his solitude; it is only amplified. His eloquence is the touch of acquired and not inborn humanity, but nevertheless it allows him to feel compassion towards humans and to be as self-reflexive as any human, Descartes and Kierkegaard included. But this capacity only makes his irreducible lack of humanity clear to him and enrages him. He is still helplessly one of a kind, but now a humanizing emotional solitude is more important than his ontological status. In a long and eloquently pleading soliloquy addressed to Frankenstein in the icy desert landscape he pleads for a companion of his own kind:

When I looked around, I saw and heard of none like me. Was I then a monster, a blot upon the earth, from which all men fled, and whom all men disowned? [...] I exclaimed in agony: 'Cursed creator! Why did you form a monster so hideous that even you turned from me in disgust? God, in pity, made man beautiful and alluring, after his own image; but my form is a filthy type of yours, more horrid even from the very resemblance. Satan had his companions, fellow-devils, to admire and encourage him; but I am solitary and abhorred. [...] No Eve soothed my sorrows, nor shared my thoughts. [...] I am alone, and miserable; man will not associate with me; but one as deformed and horrible as myself would not deny herself to me. My companion must be of the same species, and have the same defects. This being you must create. (Shelley, 2000).

However, Frankenstein refuses to produce another monster in order to humanize the first one. So, being one of a kind, a monster, he acts like a monster in a frenzy of murder and destructtion. The only difference from the old monsters is that he is a human creation, but cannot be humanized. 
The opposition between Frankenstein and his monster blurs the pre-established boundary between the human and the nonhuman, the natural and the constructed world, leaving both in a self-created solitude where they have to reflect on their identity as borderline individuals questioning the dissolving identity of humankind. As solitary beings, both embody the very boundary of humanity as it cuts through their own individual existence: Frankenstein has created a humanoid, but loses his own humanity be refusing the monster's very human wishes; the monster takes on human form and behavior, but remains nevertheless a monster. Who is the more human is impossible to decide.

In this encounter, solitude signals a disturbing instability in the fixed order of things, where the human and the non-human meet and blend, and makes visible the vicarious boundary between the fixed categories we project onto the natural and the cultural world in order to place ourselves in it as humans. What is human and what is not, has to be redefined again and again, a project that Descartes and Kierkegaard embarked on in the urban context which itself embodies this challenge. The incessant re-establishment of this difference is therefore necessary in order for solitude to be fashioned as an emotional self-assertion.

In this modern context, the ontological state of solitude, of being absolutely alone in the order of nature, inseparably merges with the humanizing individual emotional state of solitude. The modern solitary individual is not abandoned by the gods but rather by his or her fellow human beings, when they are present. The fact and the feeling of absolute aloneness are from this point inseparable, and it is precisely their entanglement that generates the self-reflection of both the monster and his maker. "Solitude - the feeling and knowledge that one is alone", Octavio Paz succinctly states in The Labyrinth of Solitude (Paz, 1985) or, as the title of Pierre Naudin's monography has it, "l"expérience et le sentiment de la solitude' (Naudin, 1995). Solitude is a situation, then, which cannot be interpreted through a simple reference to a place or to a given, larger ontological context, let alone a stable universal order, providing it with a collective significance, but only through self-reflexive embedded in an emotional state of singularity that articulates the boundary of humanity. In this move from ontological to emotional solitude the metaphysics of solitude vanishes and it is entirely integrated in the human life world.

\section{A Dialogue with the Past}

There are two strategies available for this personal, self-reflexive negotiation of the boundary of humanity to be carried out through a sense of solitude. First, projection as a cultural device exploited to push what appears to us as an unbearable foreignness, marking a limit of what is taken to be human, out of our self-chosen cultural and individual comfort zone. We project onto the world a meaning which is not really there. The second strategy is construction as a cultural device by which our own presumably self-chosen solitary separation from the foreign is inscribed in an ongoing collective discursive narrative within our culture, providing the projected meaning with a cohesive structure by which we locate ourselves in a cultural space as defined by the projection.

Both the projections and the constructions recycle fragments of texts and images of the rich classical and often cross-cultural stock of material on solitude. After classical mythologies and religious understandings of nature have been replaced by mo- dern scientific conceptions, the extra-human solitary position continues to fascinate and disturb our cultural imagination, and the old narratives and other genres are widely revitalized in new contexts across cultures, in texts, images and other cultural products disseminated in the global media culture.

The story I choose to discuss modern projections and constructions echoing a long history of images of solitude is John Michael Coetzee's novel Waiting for the Barbarians (1980), referring to Pedros Cavafy's poem from 1898. On the outskirts of an unspecified empire, vaguely like South Africa during apartheid, a middle-aged civil servant, the Magistrate, guards the border against the Barbarians, close to the desert where he lives in a peaceful symbiosis with them, their landscape and their rhythm of life and also does some archaeological excavations. He is the narrator. The brutal representatives of a central power, more thugs than soldiers, are led by Colonel Joll, ruthless and too full of himself. They arrive to prevent an alleged insurrection by the Barbarians, a danger no one else has ever heard about. Some barbarians are tracked down and tortured to reveal or rather to create a clearcut distinction between good and bad, known and foreign, in order to legitimate the persecution and the ultimate reestablishment of a sociopolitical barrier between white humanity and barbarian savageness.

And solitude? Nobody pays much attention to solitude in any sense of the term. But what they do is precisely to re-activate a host of age-old images of place, body and language by reiterating practices and discursive strategies. Since antiquity such configurations have been so closely related to the reflection on and creation of solitude that the characters, irresistibly and each in their own way, lock themselves and everybody else around them into an enclosure of solitude with no exit. There is no language to reflect on what has happened and what it means, and no emotional experience to help cope with it, only a spontaneous horror or a passive contemplative resignation. This is a trajectory to solitude.

In the beginning Joll, together with his men, simply projects the collective fear of the unknown onto the natives and constructs the identity of the humans on his own side of the border in contrast to the savages from the desert that stretches beyond the horizon in indeterminable infinitude. This construction is a radicalized version of the colonial myth of 'the white man's burden': to defend and expand civilization by suppressing or educating the barbarian peoples. As the title of Coetzee's novel indicates, this myth resonates with classical images of monsters and barbarians as the embodiment of the non-human as located in a particular marginal space where it can be identified and wiped out.

Joll's cultural logic as described by Rüdiger Safranski in his Das Böse oder Das Drama der Freiheit (1997) provides the urban paradox diagnosed by Kierkegaard and Descartes with a generalized and scaring significance in the modern world. It is not just a paradox generating solitude to contemplate the human condition. With an imagined insurrection as the reason for the presence of the soldiers and surrounded by the undifferentiated desert, there are no unquestioned structure of defining differences to identify people and objects, not even a paradoxical one. Hence, the border has to be reestablished with repeated and increasing insistence that eventually turns into acts of terror. With an implicit reference to Descartes's cogito and to the fundamental role of difference in Kierkegaard's thinking, Safranski compares this situation to a burning fire: 
Dass ich bin, mag einem in Denken gewiss werden. Aber was ich bin, erfahre ich nur im Unterschied zu den anderen. Aber auch mit der Erkenntnis des Unterschieds allein kann man noch nicht zufrieden sein. Das intensive Selbstgefühl erwächst aus dem Bewusstsein, dass man sich unterschiedet, indem man sich hervortut. Es kommt auf den Rang an. [...] Diesem Verlangen nach Differenz entspringt die grosse Gefährdung des Gesellschaftsvertrages. Der Wettkampf um die Unterschiede kann immer wieder neu entbrennen. (Safranski, 2008).

How does this competition for superiority materialize in the novel? It unfolds in a self-defeating strategy that prompts a solitude reminiscent of a Hobbesian dystopic view of human nature which is disastrous for everyone (cf. also Stirner, 1972). On the one hand, the projections and constructions build on the images derived from the context of the ontological solitude. The aim is to identify white people with the ancient heroes placed in a solitary position that makes the border of humanity as visible and stable as if carved in stone. On the other hand, the conditions to realize this aim are entirely modern: there is no clear border, only an imagined fear of the foreign that threatens to deprive the whites of their unique humanness. So, the aim and the conditions do not match and the projections and constructions fall apart. Throughout the novel they lose their validity and all the whites become isolated atoms in a void without belonging anywhere, neither white heroes nor people at home in a shared life with the natives. Panic-stricken, they enter a state of unbearable emotional solitude similar to that of Frankenstein and his monster. The images of the classical ontological solitude have exhausted their power, and the self-sought contemplative solitude of the early moderns and their followers has no value.

In a fraudulent rejection of the humanity of others - other people, other cultures - this competition for a positive selfdefinition, as Safranski puts it, produces mutual solitude on both sides. In a spiraling process of escalating terror the soldiers ultimately produce their own self-alienation, and the natives withdraw to the desert, some in despair. Solitude becomes the ultimate sign of defeat, not a road to humanity. This general breakdown of the social order constitutes a modern parallel to the cosmic upheaval in King Lear with effects of the same magnitude. The order of the universe does not break down, only the false projections and constructions that attempt to reinstall it. But the emerging solitude is equally profound.

This melt-down comes out of two parallel sets of events, one happens between the whites and the natives, the other among the whites alone. At a certain point, Joll sets out into the desert with a group of soldiers to hunt down the barbarians. But out there, Joll and his men are the foreigners and the natives are at home, the humankind of the desert: a boundless void for the whites, a readable map for the natives, who lure the troops out where they are helplessly lost. After three months a horse returns to the frontier settlement, carrying a dead soldier mounted on it like a monster, neither man nor beast. He is followed by Joll totally out of his mind, as scared as if he had seen the heart of darkness, solitary out there and also now when he is back in the town with the Magistrate. He is terrified in his self-inflicted emotional solitude like Frankenstein's monster who also, in a mixture of rage and tears, realizes that he cannot by himself transcend his solitude. Joll has been left alone in the desert by his men, scattered in all directions, nobody knows where:
'Gone. Scattered all over the place. I don't know where they are. We had to find our own way. It was impossible to keep together.' [...] 'Let me go!' he sobs. He is no stronger than a child. [...] 'We starved in the desert. Why did no one tell us it would be like that? We were not beaten - they let us out into the desert and then they vanished' (Coetzee, 1982).

The boundary of humankind does not separate the whites from the natives, but becomes visible as a split within the individual human experiencing his desperate solitude.

The second dismantling of unsubstantiated projections and constructions happens in the barracks while Joll is away. The soldiers remaining in town have nothing to do but to maintain a distance to the natives and demonstrate their own superiority. The sadistic deputy commander, Mandel, brings cruelty to a new level of ferociousness with the soldiers as rampant marauders. But, as Safranski states, in a world of mutual indifference human identity can only be established by the creation of a non-human showing that the monstrous belongs to others. This becomes clear when the Magistrate is repeatedly tortured by the soldiers, mostly to entertain themselves to avoid being more terrified than they already are, face to face with an unknown social and geographical territory around them. He is a friend of the Barbarians, they say; he is the barbarian within and must be removed by being turned into a non-human. At the end he is dressed up as a woman before they haul him up, backwards with his arms tied across his back, and make him swing, a flying human, a true species-crossing monster, crying out in pain. The soldiers laugh: "He calls his barbarian friends. It is barbarian language we hear" (Coetzee, 1982).

Taken down, the Magistrate is left to himself, still a monster: here he sees himself like a dog licking his food, unable to move arms and legs. His solitude is as profound as Joll's on his return, both of them with a weakened body and a reduced language. Joll is the victim of his own projections of fear of the foreign on the natives, the Magistrate the victim of the soldiers' need to constantly assert themselves by constructing the monstrous as being outside themselves. When Joll comes back alone, the remaining soldiers disappear as scattered individuals and, as in the beginning, the Magistrate is left with the natives, but now as a solitary being left with his remorseful ruminations. Any tacit, mutual understanding between him and the natives has disappeared. He slowly realizes that he has just been another manifestation of the imperial power, soft power in contrast to Joll's tough power, but in the end two sides of the same coin (Coetzee, 1982).

Constructions and projections of the monstrous and the barbarian have come back with a vengeance, producing a deep solitude shared by torturers and victims alike. "The crime that is latent in us we must inflict on ourselves," the Magistrate speculates, realizing that in his complacent negligence he has been as oppressive as Joll (Coetzee, 1982). If Frankenstein produced the proto-human monster outside himself, here it is unleashed inside the characters. The boundlessness of the desert rubs off on everyone with no projections or constructions to rely on, but as a story for us to contemplate.

\section{Negotiating Humanity}

Solitude, historical and contemporary, still represents a theme for a reflection on this cultural mechanism of identity formation in a permanent negotiation between need for the other 
and opposition to the other. Solitude is a construction embedded in and determined by the narratives of a collective social universe that turns solitude into a readable sign we can interpret. I know no better medium than literature for that purpose. It reworks our language by inventing forms of expression that highlight the process, showing the complexity of multiple perspectives, the dynamics of cultural boundaries and the dialogues across the history of creative thinking and imaginative writing.

Literature does not create monsters, but it may give them a name. It does not warn us of the wrath of the gods through the solitary characters at the boundary of humankind, but reminds us of our responsibility for keeping the borders open and dynamic, not a rigid opposition between us and them, turning people on both sides of the dividing line into monstrous barbarians. Literature cannot prevent monsters occurring. But via a reflection on solitude it can make us aware of how they lurk in the underworld of our identity formation and reach the surface the moment we stop renegotiating the boundaries of humankind, but take them for granted.

\section{REFERENCES}

Auster, P. (1982/1989). The invention of solitude. London: Penguin. Balzac, H. (1977/1832). Une passion dans le désert. La comédie humaine VIII. Paris: Gallimard/La Pleïade, 1221-1232.

Breitenfellner, K., \& Kohn-Levy, C. (1998). Wie ein monster entsteht. Bodenheim: Philo.

Cavafy, P. (1898). Waiting for the Barbarians.

http://www9.georgetown.edu/faculty/jod/texts/cavafy.html

Coetzee, J. M. (1982/1980). Waiting for the Barbarians. Harmondsworth: Penguin.

Defoe, D. (1965/1719). Robinson Crusoe. London: Penguin.

Descartes, R. (1991/1637). Discours de la méthode suivi de la dioptrique. Paris: Gallimard.

Donne, J. (1998/1634). Meditation 17. In M. H. Abrams, \& S. Greenblatt, (Eds.), The Norton anthology of English literature 1 (pp. 12771278). London/New York: Norton.

Engelberg, E. (2001). Solitude and its ambiguities in modernist fiction. New York: Palgrave.
Fergusson, F. (1992). Solitude and the sublime. The romantic aesthetics of individuation. London: Routledge.

Gangopadhyay, S. (1997/1981). Those days. New Delhi: Penguin India. Hall, Edith (1989). Inventing the Barbarian. Greek self-definition through tragedy. Oxford: Clarendon.

Hannoun, M. (1993). Solitudes et sociétés. Paris: Presses Universitaires Françaises.

Hassig, D. (1995). Medieval bestiaries: text, image, ideology. Cambridge: Cambridge University Press.

Kant, I. (1905/1764). Beobachtungen über das gefühl des schönen und erhabenen. Kant's gesammelte schriften II. Berlin: Königliche Preußische Akademie der Wissenschaften.

Kappler, C. (1980). Monstres, démons et merveilles à la fin du moyen age. Paris: Payot.

Kierkegaard, S. (1968). Søren kierkegaards papirer. Copenhagen: Gyldendal.

Larsen, S. E. (2004). Mostri et incontri culturali. In O. Innocenti, (Ed.), Incontri (= Quaderni di synapsis III) (pp. 24-37). Firenze: Monnier.

Moorhouse, G. (1974). The fearful void. London: Hodder and Stoughton.

Möhrmann, R. (1974). Der vereinsamte mensch: Studien zum wandel des einsamkeitsmotivs im Roman von rabe bis musil. Bonn: Bouvier.

Naudin, P. (1995). L'expérience et le sentiment de la solitude dans la littérature française de l'aube des lumières à la révolution. Paris: Klincksieck.

Paz, O. (1985). The labyrinth of solitude and other writings. New York: Grove.

Petrarca, F. (1955/c. 1350). De vita solitaria (Italian/Latin). Milano: Ricciardi.

Pliny the Elder (1961/1st Century BCE). Naturalis historia. London: Heinemann.

Safranski, R. (2008/1997). Das böse oder das drama der freiheit. Frankfurt a.M.: Fischer.

Shakespeare, W. (2001/1606). King Lear (Arden ed.). London: Thomas Learning.

Sheehan, J., \& Sosna, M. (1991). The boundaries of humanity. Berkeley: University of California Press.

Shelley, M. (2000/1817). Frankenstein. Boston: Bedford/St. Martin's.

Stirner, M. (1972/1845). Der einsame und sein eigentum. Stuttgart: Reclam.

Wittkower, R. (1977). Marvels of the east: A study in the history of monsters. In R. Wittkower (Ed.), Allegory and the migration of symbols (pp. 46-74). London: Thames and Hudson. 